\title{
URINARY EXCRETION OF AMINO ACIDS FOLLOWING THE RAPID INJECTION OF A SOLUTION OF AMINO ACIDS IN MAN 1,2
}

\author{
BY RICHARD D. ECKHARDT AND CHARLES S. DAVIDSON \\ (From the Thorndike Memorial Laboratory, Second and Fourth Medical Services [Harvard], \\ Boston City Hospital, and the Department of Medicine, Harvard Medical School, Boston)
}

(Received for publication June 12, 1948)

The parenteral administration of partial and complete protein hydrolysates is accompanied by an appreciable excretion of the infused amino acids and polypeptides in the urine (1-5). The renal loss of amino nitrogen following parenteral administration may be as great as 28 times the loss from the administration of an equivalent amount of nitrogen as whole protein orally (6). If, in addition to such urinary losses, one or more of the essential amino acids were present in "limiting" amounts or were preferentially excreted, the amount of a protein just capable of maintaining nitrogen equilibrium when given orally might be insufficient when given intravenously as a hydrolysate (6).

The experiments reported here were undertaken to determine the extent of the renal loss of amino acids after their intravenous infusion. Determinations were made of the renal excretion of the eight amino acids essential for man (7) and of arginine and histidine, the urinary excretion of alpha amino nitrogen, and the blood alpha amino nitrogen following the intravenous administration to normal subjects of a 10 per cent solution of amino acids. The results indicate that the administration of protein or amino acids orally or intravenously, slowly or rapidly, and in large or small quantity is followed by the excretion in the urine of but a small portion of that administered.

\section{MATERIALS AND METHODS}

The amino acid mixture ${ }^{3}$ was made by the complete acid hydrolysis of casein, contains no peptides, is essen-

\footnotetext{
1 The expenses of this investigation were defrayed in part by a grant from Merck and Company, Inc., Rahway, New Jersey, to Harvard University.

2 A preliminary report of this investigation was included in the Proceedings of the Thirty-Ninth Annual Meeting of the American Society for Clinical Investigation, May 5, 1947.

3 "Solution of Amino Acids Mixture, 10\%," developed and distributed by Merck \& Co., Inc., Rahway, N. J., who supplied the material used in this investigation.
}

tially devoid of the dicarboxylic amino acids (glutamic and aspartic) and is supplemented with dl-methionine, dltryptophane, and glycine so that it contains the eight amino acids essential for man (7). In Table I the composition of the lot of the solution of amino acids employed in this study is shown and is compared to that of casein. The results are all based on analyses by microbiological assay $(8-10)$.

The normal subjects selected for this study were medical students or interns. The urine was collected for one day prior to the infusions during which time the subjects ate ad libitum. The last two-hour urine collection (6 to 8 a.m.) of the 24-hour control period was saved separately, and thus represented a two-hour fasting specimen in contrast to the preceding 22-hour non-fasting collection. Each $500-c c$. infusion of the 10 per cent solution of amino acids supplied $47 \mathrm{gm}$. of amino acids, $7.5 \mathrm{gm}$. of total nitrogen, and $6.0 \mathrm{gm}$. of alpha amino nitrogen, and was given without glucose to the subjects while fasting. Blood samples for plasma alpha amino nitrogen determinations were obtained prior to the infusion and at fiveminute, one-hour, and four-hour intervals after the infu-

TABLE I

Comparison of the composition of the $10 \%$ solution of amino acids with casein

\begin{tabular}{l|c|c|c}
\hline \hline & $\begin{array}{c}\text { Amino acid } \\
\text { solution }\end{array}$ & Caseint & $\begin{array}{c}\text { Amino acid } \\
\text { solution }\end{array}$ \\
\hline & $\begin{array}{c}\text { gm. per liter of } \\
\text { 10\% solution* }\end{array}$ & $\begin{array}{c}\text { gm. per } \\
100 \text { gm. }\end{array}$ & $\begin{array}{c}500 \text { cc. of } 10 \% \\
\text { gm. per } \\
\text { injection }\end{array}$ \\
Arginine & 4.9 & 3.7 & 2.5 \\
Histidine & 3.1 & 2.8 & 1.6 \\
Isoleucine & 7.6 & 6.9 & 3.8 \\
Leucine & 15.6 & 10.1 & 7.8 \\
Lysine & 8.4 & 7.6 & 4.2 \\
Methionine & 6.4 & 2.8 & 3.2 \\
Phenylalanine & 5.3 & 5.3 & 2.7 \\
Threonine & 2.1 & 4.3 & 1.1 \\
Tryptophane & 0.9 & 1.2 & 0.45 \\
Valine & 6.2 & 6.2 & 3.1 \\
\hline
\end{tabular}

* Determinations by microbiological assay (l-form) (8). Also contains: $0.9 \mathrm{gm}$. d-tryptophane, $2.5 \mathrm{gm}$. d-methionine, $0.2-0.5 \mathrm{gm}$. glutamic acid, $0.2 \mathrm{gm}$. tyrosine, $22.6 \mathrm{gm}$. glycine, less than $0.05 \mathrm{gm}$. aspartic acid, and (by difference) $7.0 \mathrm{gm}$. non-assayed amino acids per liter of 10 per cent solution. Total 10 "essential" amino acids (l-form) comprise 64 per cent of total amino acids in mixture.

$\dagger$ Averaged values of Stokes et al. (8), Hodson and Krueger (9), and Pearce et al. (10). Microbiological assay. $\ddagger$ Each $500 \mathrm{cc}$. infusion supplies $47 \mathrm{gm}$. of amino acids, $7.5 \mathrm{gm}$. of total nitrogen, and $6.0 \mathrm{gm}$. of alpha amino nitrogen. 
sion had been completed. The urine was collected during this four-hour period, 4 and separately over the next 20 hours. Food was withheld until four hours after the infusion, and was then ingested as for the preceding control day.

The alpha amino nitrogen was determined by the gasometric ninhydrin method as described by Hamilton and Van Slyke for plasma (11), and by Van Slyke, MacFadyen, and Hamilton for urine (12). All individual amino acid analyses in the urine were by microbiological assay (8). Since the unnatural isomers of methionine and tryptophane are not detected by microbiological assay (8), all values presented here are for the naturally occurring 1-forms, although both $\mathrm{d}$ - and 1-methionine are nutritionally available for man (13). We have, therefore, no data concerning the loss by renal excretion of the $d-$ methionine and d-tryptophane infused in these subjects.

\section{RESULTS}

In Table II are shown the blood amino nitrogen values and the urinary excretion of alpha amino nitrogen following the infusion of $500 \mathrm{cc}$. of the 10 per cent solution of amino acids in the eight normal subjects. The solution of amino acids was infused at varying rates that fall roughly into three

4 This specimen was collected from the time the infusion started until four hours after its conclusion, and thus covered somewhat more than four hours' time. For purposes of calculation, it was considered a four-hour collection since the infusion time was short enough to make the error so incurred negligible. rate periods of (a) $2 \mathrm{mgm}$. of nitrogen per kilogram per minute, (b) $6 \mathrm{mgm}$. of nitrogen per kilogram per minute, and $(c) 10 \mathrm{mgm}$. of nitrogen per kilogram per minute. These infusion rates roughly correspond to the infusion of $50 \mathrm{gm}$. of amino acids to a $70 \mathrm{kgm}$. subject in $(a)$ one hour, (b) 20 minutes, and (c) 10 minutes. All infusions supplied over $0.5 \mathrm{gm}$. of amino acids per kilogram of body weight. There were no reactions to the infusions save for transient nausea without vomiting in two subjects who received the solution at the most rapid rate.

The control non-fasting 24-hour urine alpha amino nitrogen excreted by these eight normal subjects averaged $158 \mathrm{mgm}$. daily (Table II). The extremes (120 and $199 \mathrm{mgm}$. daily) probably reflect the varied protein intake of their diets, estimated to range from 80 to $130 \mathrm{gm}$. daily. Per hour, these non-fasting values for urinary amino nitrogen averaged $6.6 \mathrm{mgm}$. (range 5.0 to 8.3 ) which is higher than the average fasting value of $4.3 \mathrm{mgm}$. per hour (range 3.7 to 5.7 ) as determined by the two-hour pre-injection urine collection in these subjects. The difference of $2.3 \mathrm{mgm}$. per hour or $55 \mathrm{mgm}$. daily can be considered the renal loss from the protein ingested by these subjects. An estimated average protein intake of $105 \mathrm{gm}$. daily would represent about $16.8 \mathrm{gm}$. of

TABLE II

Blood alpha amino nitrogen values and urine alpha amino nitrogen excreted after injection of 500 cc. of $10 \%$ solution of amino acids at varying rates of infusion in eight normal adult subjects

\begin{tabular}{|c|c|c|c|c|c|c|c|c|c|c|c|c|c|c|}
\hline \multirow{3}{*}{$\begin{array}{l}\text { Rate } \\
\text { period }\end{array}$} & \multirow{3}{*}{ Subject } & \multirow{3}{*}{$\begin{array}{l}\text { Infusion } \\
\text { rate }\end{array}$} & \multicolumn{4}{|c|}{ Blood alpha amino nitrogen } & \multicolumn{8}{|c|}{ Urine alpha amino nitrogen } \\
\hline & & & \multirow{2}{*}{ Control } & \multicolumn{3}{|c|}{ Time after infusion } & \multirow{2}{*}{ Control* } & \multicolumn{7}{|c|}{ Time after infusion } \\
\hline & & & & $5 \mathrm{~min}$. & $1 \mathrm{hr}$. & $4 \mathrm{hrs}$. & & \multicolumn{2}{|c|}{0 to 4 hours } & \multicolumn{2}{|c|}{4 to 24 hours } & \multicolumn{3}{|c|}{ Total 24 hours } \\
\hline & & $\underset{\mathrm{kgm} . / \mathrm{min}}{\operatorname{mgm}}$. & \multicolumn{4}{|c|}{ mgm./100 cc. plasma } & $\begin{array}{l}\text { mgm./ } \\
24 \text { hrs. }\end{array}$ & $\begin{array}{l}\text { excess } \\
\text { mgm. } \\
4 \mathrm{hrs} . \dagger\end{array}$ & $\begin{array}{c}\text { per cent } \\
\text { excreted } \ddagger\end{array}$ & $\begin{array}{c}\text { excess } \\
\text { mgm. } \\
20 \text { hrs.t }\end{array}$ & $\begin{array}{c}\text { per cent } \\
\text { excreted } \ddagger\end{array}$ & $\begin{array}{c}\text { excess } \\
\text { mgm./ } \\
24 \text { hrs. }\end{array}$ & $\begin{array}{l}\text { per cent } \\
\text { excreted } \ddagger\end{array}$ & $\begin{array}{l}\text { average } \\
\text { per cent } \\
\text { excreted } \neq\end{array}$ \\
\hline I & $\begin{array}{l}\text { N. D. } \\
\text { J. T. }\end{array}$ & $\begin{array}{l}1.9 \\
2.0\end{array}$ & $\begin{array}{l}3.3 \\
3.5\end{array}$ & \begin{tabular}{|l|}
16.3 \\
12.5
\end{tabular} & $\begin{array}{l}6.8 \\
6.1\end{array}$ & $\begin{array}{l}4.1 \\
3.8\end{array}$ & $\begin{array}{l}154 \\
180\end{array}$ & $\begin{array}{l}477 \\
441\end{array}$ & $\begin{array}{l}7.9 \\
7.3\end{array}$ & $\begin{array}{r}15 \\
4\end{array}$ & $\begin{array}{l}0.3 \\
0.1\end{array}$ & $\begin{array}{l}492 \\
445\end{array}$ & $\begin{array}{l}8.2 \\
7.4\end{array}$ & 7.8 \\
\hline II & $\begin{array}{l}\text { W. D. } \\
\text { T. C. } \\
\text { A. G. }\end{array}$ & $\begin{array}{l}5.8 \\
6.4 \\
6.6\end{array}$ & $\begin{array}{l}3.4 \\
4.2 \\
3.8\end{array}$ & $\begin{array}{l}23.2 \\
24.7 \\
24.3\end{array}$ & $\begin{array}{l}8.9 \\
7.4 \\
7.3\end{array}$ & $\begin{array}{l}3.8 \\
4.2 \\
4.2\end{array}$ & $\begin{array}{l}139 \\
199 \\
160\end{array}$ & $\begin{array}{l}489 \\
715 \\
439\end{array}$ & $\begin{array}{r}8.2 \\
11.9 \\
7.3\end{array}$ & $\begin{array}{r}18 \\
2 \\
4\end{array}$ & $\begin{array}{l}0.3 \\
0.0 \\
0.1\end{array}$ & $\begin{array}{l}507 \\
717 \\
444\end{array}$ & $\begin{array}{r}8.5 \\
11.9 \\
7.4\end{array}$ & 9.3 \\
\hline III & $\begin{array}{l}\text { F. E. } \\
\text { A. B. } \\
\text { J. S. }\end{array}$ & $\begin{array}{r}9.0 \\
9.6 \\
11.6\end{array}$ & $\begin{array}{l}4.1 \\
3.3 \\
3.2\end{array}$ & $\begin{array}{l}27.4 \\
22.8 \\
28.6\end{array}$ & $\begin{array}{l}7.3 \\
6.1 \\
7.4\end{array}$ & $\begin{array}{l}4.4 \\
3.1 \\
3.6\end{array}$ & $\begin{array}{l}158 \\
120 \\
156\end{array}$ & $\begin{array}{l}756 \\
469 \\
656\end{array}$ & $\begin{array}{r}12.6 \\
7.8 \\
10.9\end{array}$ & $\begin{array}{r}4 \\
32 \\
18\end{array}$ & $\begin{array}{l}0.1 \\
0.5 \\
0.3\end{array}$ & $\begin{array}{l}760 \\
501 \\
674\end{array}$ & $\begin{array}{r}12.7 \\
8.3 \\
11.2\end{array}$ & 10.7 \\
\hline \multicolumn{2}{|c|}{ Average 8 infusions } & 6.6 & 3.6 & 22.5 & 7.2 & 3.9 & 158 & 555 & 9.3 & 12 & 0.2 & 568 & \multicolumn{2}{|c|}{9.5} \\
\hline
\end{tabular}

* Mgm. alpha amino nitrogen excreted while receiving the ad libitum diet.

† Mgm. alpha amino nitrogen in excess of that excreted while receiving the ad libitum diet.

$\ddagger$ Per cent of administered alpha amino nitrogen (Table I) excreted in urine. 
TABLE III

Ten "essential" amino acids excreted in urine (mgm. per 24 hours) by eight normal adult subjects receiving ad libitum diets

\begin{tabular}{l|r|r|r|r|r|r|r|r|r|r|r|r}
\hline \hline Subject & Arg. & Hist. & Isol. & Leuc. & Lys. & Meth. & Phen. & Threo. & Tryp. & Val. \\
\cline { 2 - 7 } N. D. & 9.9 & 152 & 17.3 & 7.0 & 37.0 & 3.8 & 8.6 & 21.6 & 13.0 & 7.7 \\
J. T. & 9.7 & 218 & 12.5 & 7.5 & 99.9 & 4.8 & 19.1 & 34.6 & 14.7 & 9.0 \\
W. D. & 8.0 & 91 & 11.2 & 3.3 & 87.2 & 4.4 & 7.6 & 14.6 & 9.7 & 6.2 \\
T. C. & 13.8 & 198 & 7.5 & 11.4 & 26.5 & 6.8 & 19.4 & 37.5 & 16.5 & 11.4 \\
A. G. & 12.8 & 169 & 11.3 & 10.9 & 42.9 & 5.7 & 28.0 & 16.4 & 12.9 & 8.7 \\
F. E. & 3.0 & 123 & 13.8 & 3.6 & 22.8 & 2.0 & 6.6 & 7.7 & 11.6 & 2.7 \\
A. B. & 9.0 & 133 & 23.6 & 7.4 & 20.4 & 3.8 & 10.8 & 15.0 & 9.2 & 7.4 \\
J. S. & 9.6 & 222 & 13.1 & 6.5 & 37.6 & 4.1 & 11.8 & 20.1 & 13.8 & 6.4 \\
\hline Average & 9.5 & 163 & 13.8 & 7.2 & 46.8 & 4.4 & 14.0 & 20.9 & 12.7 & 7.4 \\
8 normals & & & & & & & & & &
\end{tabular}

total nitrogen ( $\mathrm{P} \times 16$ per cent) and $13.4 \mathrm{gm}$. of amino nitrogen ( $\mathrm{N} \times 80$ per cent), or an excretion loss of amino nitrogen of approximately 0.4 per cent of that ingested. The urinary excretion of the 10 individual amino acids in the eight normal subjects on ad libitum diets is tabulated in Table III.

The fasting blood alpha amino nitrogen values averaged $3.6 \mathrm{mgm}$. per $100 \mathrm{cc}$. of plasma and are in agreement with values previously found in this laboratory (14). The values showed a greater elevation the more rapid the injection five minutes after the infusion was completed, but the one-hour and four-hour post-injection values were quite comparable for all rates of infusion. Although the four-hour values fell to within normal limits, most were slightly above the pre-injection level and averaged $3.9 \mathrm{mgm}$. per $100 \mathrm{cc}$. of plasma. More

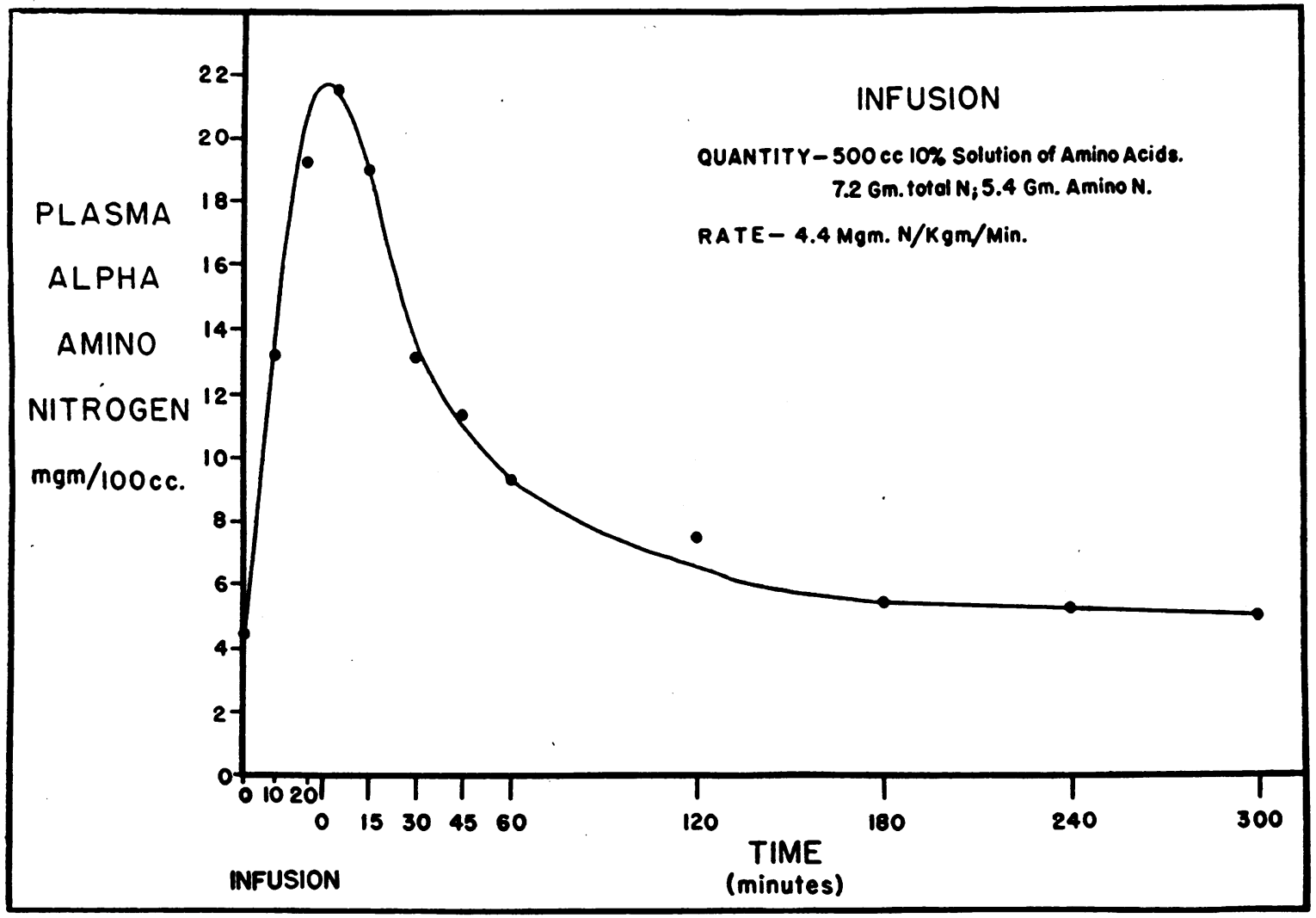

Fig. 1. Changes in the Plasma Alpha Amino Nitrogen Concentration following the Infitsion of 500 cc. of the $10 \%$ Sqlution of Amino Acids 
TABLE IV

Ten "essential" amino acids excreted in urine in the 24 hours after injection of 500 cc. of $10 \%$ solution of amino acids at varying rates of infusion (eight normal adults)

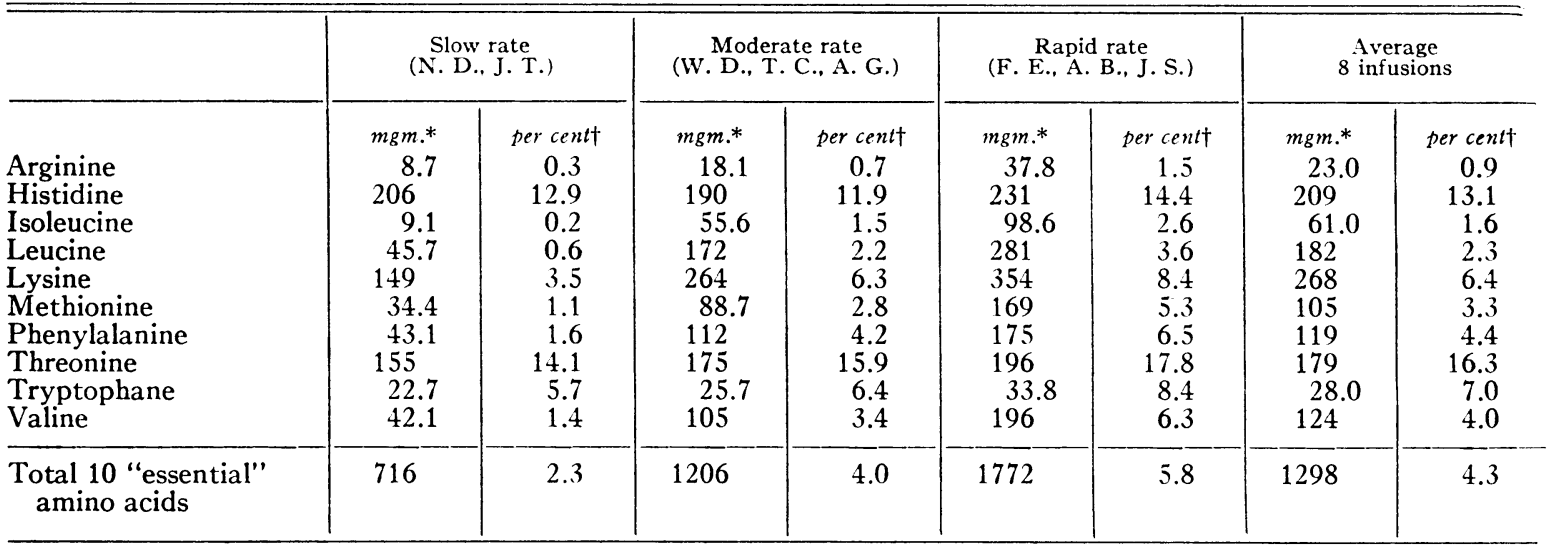

* Mgm. of amino acid in excess of that excreted while receiving the ad libitum diet (Table III).

$\dagger$ Per cent of administered amino acid (Table I) excreted in urine.

frequent determinations of plasma alpha amino nitrogen before, during, and following the infusion of the same quantity of amino acids in another subject are shown in Figure 1. It is apparent that the rapid decline in the blood amino nitrogen occurs in the first hour after the infusion, while the subsequent decline toward normal is much slower.

The excess excretion of amino nitrogen above the control occurred within the first four hours following the infusion, averaged 9.3 per cent of

\section{INFUSION}

$500 \mathrm{CC} 10 \%$ SOLUTION OF AMINO ACIDS

SLOW - 2 MGM. N./KGM./MIN. ( I HOUR)

MOD. - 6 MGM. N./KGM./MIN. (20 MIN.)

RAPID-1O MGM. N./KGM./MIN.(-IO MIN.)

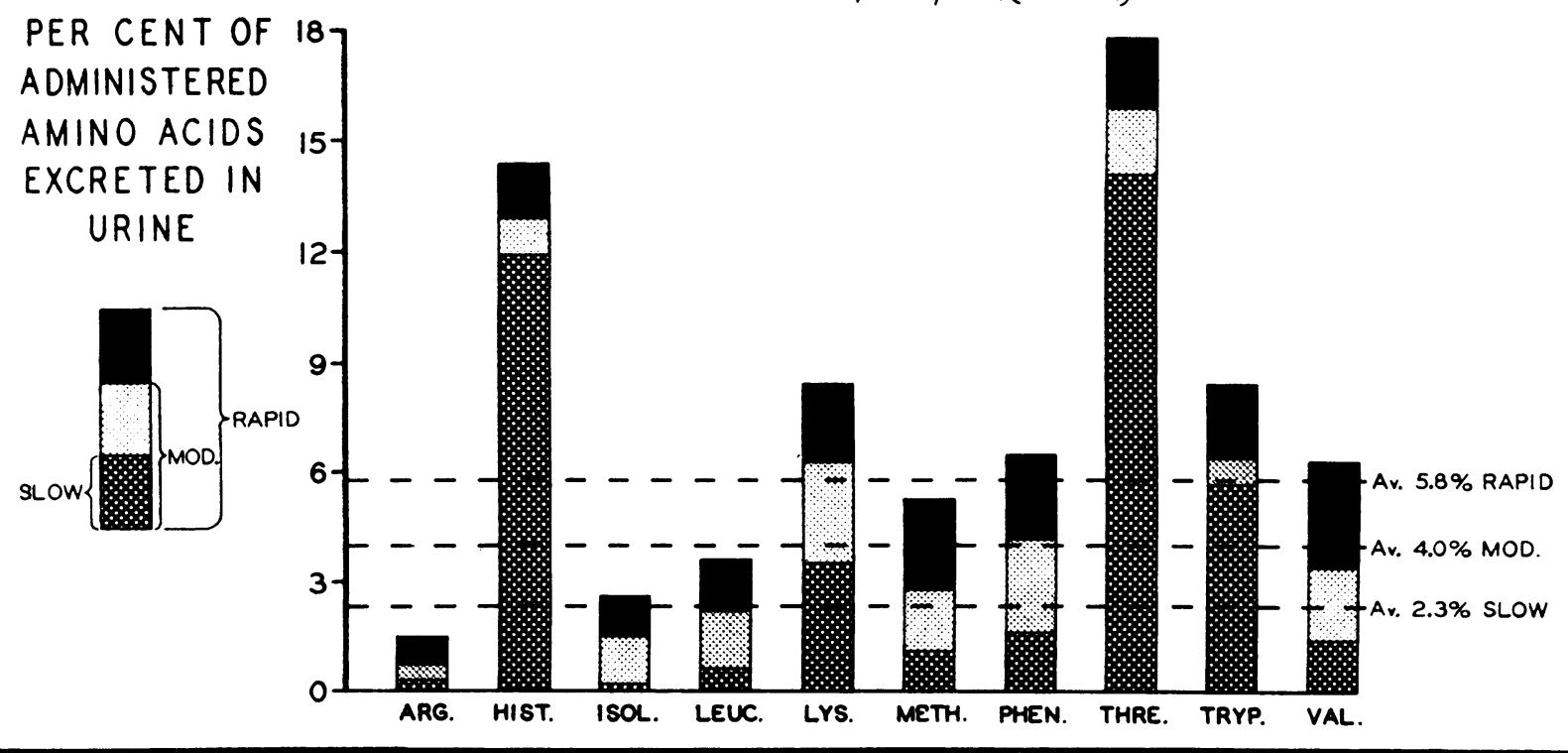

Fig. 2. Comparison of the Percentage of Administered Amino Acids Excreted in the Urine following the Infusion of $500 \mathrm{cc}$. of the $10 \%$ Solution of Anino Acids at Tirree Rates 
that infused, and coincided with the return of the blood amino nitrogen to within normal limits. ${ }^{5}$ The loss of amino nitrogen in the subsequent 20 hour collection period was negligible and averaged 0.2 per cent of that injected. The loss of amino nitrogen in the urine increased but little with more rapid infusions (Table II).

The loss in the urine of each of the infused 10 "essential" amino acids 24 hours following the injection at the different rates of infusion is tabulated in Table IV and plotted in Figures 2 and 3. Since the excess excretion above the control of each of the 10 infused amino acids occurred within four hours following the infusion with no further loss over the next 20 hours, only the total 24 -hour

5 Two additional subjects in whom the urine was collected more frequently in the post-infusion period excreted approximately 90 per cent of the amino nitrogen lost within the first hour and the remaining 10 per cent during the next three hours. post-injection values are listed. From 0.2 per cent to 14.1 per cent of the individual amino acids infused was excreted in the urine at the slow rate of infusion, and averaged 2.3 per cent for all 10 amino acids assayed. Thus the subjects excreted fairly large percentages of administered threonine and histidine, intermediate percentages of tryptophane and lysine, and smaller percentages of the other amino acids.

As the infusion rate increased from slow to moderate to rapid, an additional 1.7 per cent and 1.8 per cent, respectively, of the administered 10 "essential" amino acids was excreted. However, in contrast to the marked variation in the excretion loss of individual amino acids at the slow rate of infusion ( 0.2 to 14.1 per cent), their additional loss with more rapid infusions varied but little (from 0.0 to 2.0 per cent), as illustrated in Figure 2. Thus, for example, at the slow rate of infusion

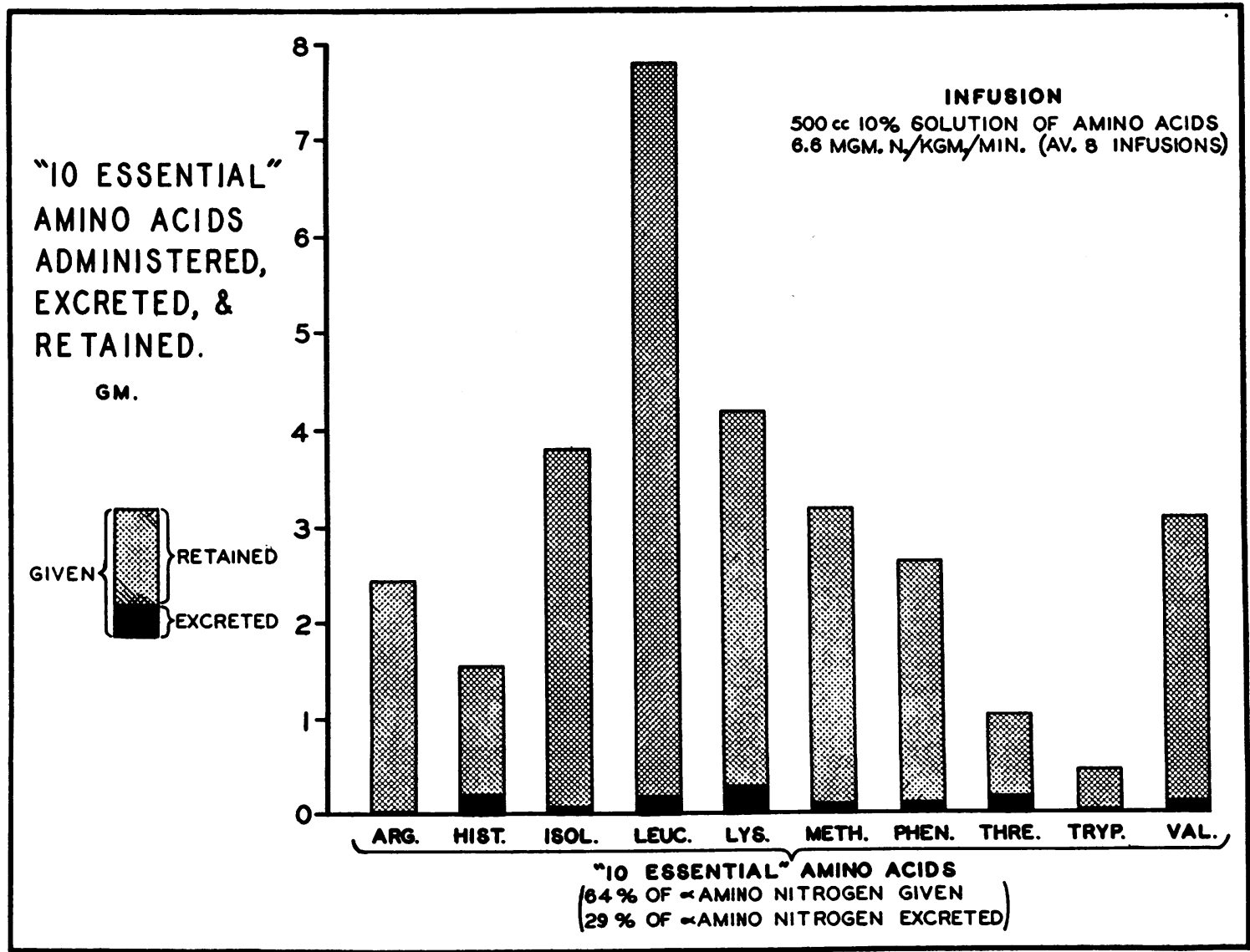

Fig. 3. Retention in the Body and Urinary Excretion of the 10 "Essential" Amino Acids following the Infusion of $500 \mathrm{cc}$. of the 10\% Solution of Amino Acids 
14.1 per cent of the administered threonine was excreted in the urine in contrast to but 0.6 per cent of the leucine given. Yet the additional loss of each of these amino acids with more rapid rates of infusion was approximately the same (1.8 and 1.9 per cent for threonine, and 1.6 and 1.4 per cent for leucine). Because of the marked variation in the percentage excretion of individual amino acids at the slow rate of infusion, it is apparent that a 2 per cent additional loss represents a considerable variation in the quantity of each amino acid excreted with more rapid rates. Thus, the additional loss of 1.8 per cent threonine and 1.6 per cent leucine at the moderate as compared to the slow rate of infusion represents for threonine only a small increase in the quantity excreted (from 155 to 175 mgm. or a 13 per cent increase), but a considerable increase in the quantity of leucine excreted (from 46 to $172 \mathrm{mgm}$. or a 275 per cent increase).

The patterns of the 10 "essential" amino acids administered intravenously, excreted in the urine, and (by difference) retained in the body are shown in Table $\mathrm{V}$ and Figure 4. The proportion of each of the "essential" amino acids in the mixture dif-
TABLE V

Pattern of the 10 "essential" amino acids administered, excreted and retained

\begin{tabular}{|c|c|c|c|c|c|c|}
\hline & \multicolumn{2}{|c|}{ Administered* } & \multicolumn{2}{|c|}{ Excreted $†$} & \multicolumn{2}{|c|}{ Retained $\ddagger$} \\
\hline & $m g m$. & $\begin{array}{l}\text { per cent } \\
\text { of total }\end{array}$ & $m g m$. & $\begin{array}{l}\text { per cent } \\
\text { of total }\end{array}$ & $m g m$. & $\begin{array}{l}\text { per cent } \\
\text { of total }\end{array}$ \\
\hline Arginine & 2,450 & 8.1 & 23 & 1.8 & 2,427 & 8.4 \\
\hline Histidine & 1,550 & 5.1 & 209 & 16.1 & 1,341 & 4.6 \\
\hline Isoleucine & 3,800 & 12.6 & 61 & 4.7 & 3,739 & 12.9 \\
\hline Leucine & 7,800 & 25.7 & 182 & 14.0 & 7,618 & 26.4 \\
\hline Lysine & 4,200 & 13.9 & 268 & 20.6 & 3,932 & 13.6 \\
\hline Methionine & 3,200 & 10.6 & 105 & 8.1 & 3,095 & 10.7 \\
\hline Phenylalanine & 2,650 & 8.8 & 119 & 9.2 & 2,531 & 8.7 \\
\hline Threonine & 1,050 & 3.5 & 179 & 13.8 & 871 & 3.0 \\
\hline Tryptophane & 450 & 1.5 & 28 & 2.2 & 422 & 1.4 \\
\hline Valine & 3,100 & 10.2 & 124 & 9.5 & 2,976 & 10.3 \\
\hline Total & 30,250 & 100.0 & 1,298 & 100.0 & 28,952 & 100.0 \\
\hline
\end{tabular}

* Table I.

† Table IV, averaged values of eight infusions.

$\ddagger$ Quantity administered minus quantity excreted.

fered considerably from that excreted in the urine. Those amino acids excreted in greater proportions than were present in the mixture (threonine, histidine, and to a lesser extent lysine and tryptophane) were the same amino acids lost in the greatest per-

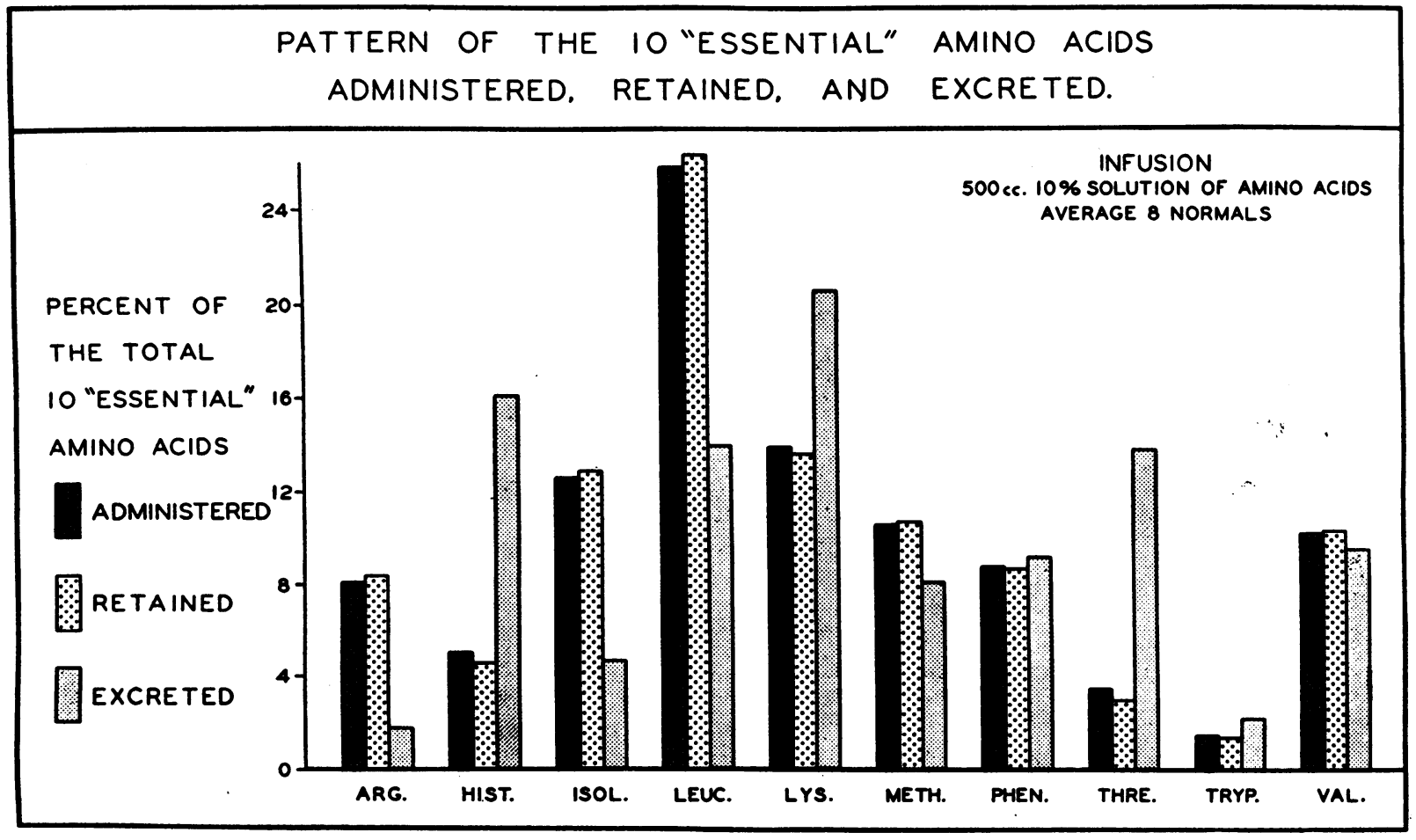

Fig. 4. Comparison of the Pattern of the 10 "Essential" Amino Acids Administered, Retained, and Excreted following the Infusion of 500 cc. of the $10 \%$ Solution of Amino Acids to Eight Normal Subụects 
centages of the amount given (Figure 2). Thus, for example, although threonine comprised only 3.5 per cent of the total 10 "essential" amino acids in the mixture infused, it contributed to 13.8 per cent of the total of these 10 amino acids excreted in the urine following the infusion, or a loss of 16.3 per cent of the threonine administered. Since only a small portion of the infused amino acids was lost in the urine (Figure 3 ), the pattern of the amino acids retained in the body resembled quite closely the pattern infused.

\section{DISCUSSION}

There is no ideal substitute for a well balanced oral diet. Nevertheless, there are instances in which supplemental or complete feeding by other routes is indicated. Whenever the parenteral route for protein nutrition is selected, the most nutritious and efficient preparation that is least objectionable to both patient and physician should be employed.

It was pointed out in a previous communication that the complete hydrolysate with which the studies reported here were conducted offers certain distinct advantages over other available preparations (15). Most evident is the reduced incidence of anorexia and nausea following administration, permitting infusion rates to be greatly increased. In addition, administration of this preparation is free from the uncertainties of the antigenicity of peptides and of the degree and rate of their utilization $(4,5)$. Fortunately even with hydrolysates containing peptides allergic reactions are but rarely encountered. Moreover, since this hydrolysate is a mixture of free amino acids for which the composition is known, it is possible to measure the urinary loss of the individual amino acids, as well as the total alpha amino nitrogen.

The results of the present investigation have shown that following infusions of $50 \mathrm{gm}$. of amino acids there is an average loss into the urine of from 1 to 16 per cent of the individual amino acids infused, of 4.3 per cent of the 10 "essential" amino acids injected, and of 9.5 per cent of the alpha amino nitrogen administered. ${ }^{6}$ The excretion of

\footnotetext{
6 Because neither food nor glucose was supplied with the amino acid infusions, our values probably represent maximum urinary losses since optimum sparing of nitrogen (and presumably amino nitrogen) occurs only if adequate carbohydrate and protein are simultaneously provided (16).
}

both alpha amino nitrogen and individual amino acids was completed within four hours after the infusion by which time the elevated blood amino nitrogen had returned to within normal limits. The urinary loss of amino acids following infusion may be contrasted with that following the ingestion of an estimated $105 \mathrm{gm}$. of protein by our subjects in the day prior to infusion which only increased the excretion of amino nitrogen above the fasting level by $55 \mathrm{mgm}$. daily, or approximately $0.4 \mathrm{per}$ cent of the ingested amino nitrogen. This value is identical with that observed to follow the oral ingestion of $50 \mathrm{gm}$. of whole casein (6).

The renal excretion of amino nitrogen was only slightly less at slow than at rapid rates of infusion. However, three of the subjects (T. C., F. E., and J. S., Table II) did excrete larger quantities of alpha amino nitrogen than did the others. Two of these (F. E. and J. S.) were of small stature and received proportionately greater quantities of amino acids per kilogram of body weight. This suggested that the urinary loss of amino nitrogen following infusions of a protein hydrolysate might correlate better with the quantity of material infused than with the rate of infusion. To substantiate this, the amino nitrogen excretion following 32 infusions of $500 \mathrm{cc}$. of the 10 per cent solution of amino acids was compared with that following 16 infusions of $1000 \mathrm{cc}$. administered to normal subjects on nitrogen balance studies. There was an average loss of 9.3 per cent (range 3.3 to 13.1 per cent) of the infused amino nitrogen in the first group and 14.0 per cent (range 8.5 to 18.7 per cent) in the second. Although in these two groups there was again no significant relationship between the rate of infusion and the urinary excretion of amino nitrogen, there was an increased excretion upon doubling the quantity given.

The significance and interpretation of the urinary excretion of amino acids has been the object of extensive investigation. All of the amino acids that have been studied are almost totally reabsorbed by the renal tubules at normal plasma concentrations $(17,18)$ so that normally only small quantities of amino acids are found in human urine. The values for the 10 "essential" amino acids excreted daily by our eight normal subjects while on ad libitum diets (Table III) are in general agreement with the published values obtained by others employing microbiological methods (19-21), al- 
though slightly higher perhaps because of the liberal protein diets of our subjects.

Following the infusion of the solution of amino acids all ten were found in greatly increased quantities in the urine during the four hours following the infusion, while none exhibited a "delayed" excretion over the next 20 hours. The excretion in the urine of the total of the 10 amino acids averaged 4.3 per cent of the quantity injected (Table IV), while that of the alpha amino nitrogen averaged 9.5 per cent of that given (Table II). The higher value for amino nitrogen probably reflects the urinary excretion of those amino acids contained in the hydrolysate but not assayed, for 36 per cent of the amino nitrogen in the solution administered consists of glycine and other non-essential amino acids, as well as d-tryptophane and d-methionine (Table I). Moreover, although the 10 "essential" amino acids comprised 64 per cent of the amino acids infused, they contributed to less than one-third of the total amino nitrogen excreted in the urine (Table VI). Thus the subjects appeared to preferentially retain the essential amino acids; and, conversely, the dispensable amino acids were more freely excreted in the urine. As a group, the 10 "essential" amino acids were retained to the greatest degree at the slowest rate of infusion, and were relatively less well conserved with more rapid infusions.

There was a marked variation observed in the percentage excretion in the urine of the individual amino acids infused (Table IV and Figure 2). It is not possible from data available to ascertain why

TABLE VI

Relation between rate of infusion and quantity of amino acids excreted in urine in the 24 hours after injection of $500 \mathrm{cc}$. of $10 \%$ solution of amino acids

\begin{tabular}{|c|c|c|c|c|}
\hline $\begin{array}{c}\text { Infusion } \\
\text { rate }\end{array}$ & $\begin{array}{c}\text { Total amino } \\
\text { acids } \\
\text { excreted* }\end{array}$ & $\begin{array}{c}\text { Total } \\
10 \\
\text { "essential" } \\
\text { amino acids } \\
\text { excretedt }\end{array}$ & $\begin{array}{l}\text { Amino acids } \\
\text { not assayed } \\
\text { (by } \\
\text { difference) }\end{array}$ & $\begin{array}{c}10 \\
\text { "essential" } \\
\text { amino acids }\end{array}$ \\
\hline $\begin{array}{l}\text { Slow } \\
\text { Moderate } \\
\text { Rapid }\end{array}$ & $\begin{array}{l}g m . \\
3.66 \\
4.34 \\
5.04\end{array}$ & $\begin{array}{l}g m . \\
0.72 \\
1.21 \\
1.77\end{array}$ & $\begin{array}{l}g m . \\
2.94 \\
3.13 \\
3.27\end{array}$ & $\begin{array}{c}\text { per cent } \\
\text { of total } \\
20 \\
28 \\
35\end{array}$ \\
\hline $\begin{array}{l}\text { Average all } \\
\text { rates }\end{array}$ & 4.44 & 1.30 & 3.14 & 29 \\
\hline
\end{tabular}

* Calculated from ${ }^{\text {tamino }}$ nitrogen excretion values, Table II, assuming $\alpha$-amino nitrogen to be $80 \%$ of total nitrogen, and total nitrogen to be $16 \%$ of amino acids. $\uparrow$ Determined by microbiological assay, Table IV. each of the amino acids was not excreted in the urine in the same proportion as administered (Table V and Figure 4). At least three explanations exist: (1) differences in the quantity of amino acids infused as compared to their requirements by the body; (2) differences in the renal clearance of amino acids; and (3) differences in the rate of removal of amino acids from the blood stream by tissues. With each increase in the rate of infusion, however, an almost equivalent additional per cent of each amino acid administered was excreted in the urine. Thus with more rapid infusions a constant proportion of that given was lost. The question may now be asked: Does the increased excretion in the urine of amino acids when parenteral rather than oral administration is employed significantly decrease the quantity of amino acids available to the body for metabolic purposes? This might be true if protein containing minimum quantities of each of the essential amino acids administered orally in an amount just sufficient to maintain nitrogen equilibrium were injected as a hydrolysate intravenously. Thus it was observed in a previous study (6) that a protein hydrolysate which contained minimum amounts of phenylalanine maintained nitrogen equilibrium when administered orally, but was incapable of sustaining nitrogen balance when given parenterally until additional phenylalanine was provided. Moreover, were an essential amino acid preferentially excreted into the urine following intravenous administration, the quantity available for metabolic purposes would be further reduced. In this regard it was observed that greater proportions of the administered threonine, histidine, and to a lesser extent lysine and tryptophane were excreted than of the other six amino acids. It is not possible to decide from the available data whether this represents preferential excretion rather than simply loss of these amino acids above the body's requirements. If amino acids are being preferentially excreted, additional quantities might have to be provided.

Further, it might be asked: To what extent is the nutritive value of the hydrolysate decreased by rapid or by large infusions? As illustrated in Figures 3 and 5 , the administration of protein or amino acids orally or intravenously, slowly or rapidly, and in large or small quantity, is followed by excretion in the urine of but a small portion of 


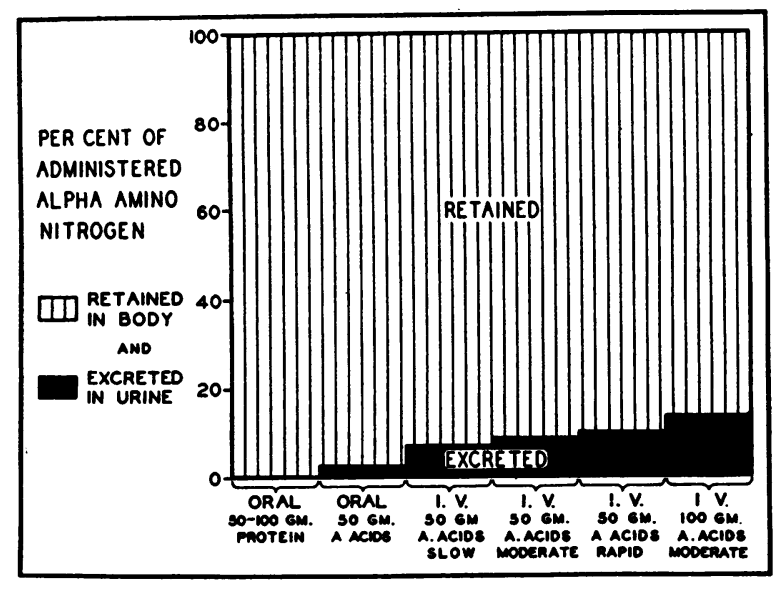

Fig. 5. Comparison of the Percentage of Alpha Amino Nitrogen Excreted following the Oral Administration of Protein or Amino Acids and the Intravenous Infusion of Amino Acids at Varying Rates and in Varying Amounts

the amino acids given. Although the loss following the parenteral administration of the protein hydrolysate was approximately 25 times greater than when protein was ingested orally, the largest quantity of amino acids excreted was so small in terms of grams of protein that the body retained for metabolic purposes more than 85 per cent of the protein given. Infusions of smaller quantities of the solution of amino acids than employed in this study might be expected to result in a smaller urinary loss of amino acids, but this small saving would not be of value since the quantity thus infused would be less than the need of the individual. Similarly, very slow infusions might result in a saving to the body of an additional few grams of the infused amino acids, but the inconvenience so incurred by both patient and physician would hardly appear to justify this practice since one of the advantages of this hydrolysis is the rapidity of infusion attainable in both animals (22) and man (15) with but few untoward effects.

\section{SUMMARY}

The 10 per cent solution of amino acids employed in this study was prepared by the complete acid hydrolysis of casein, contains no peptides, is devoid of the dicarboxylic amino acids (glutamic and aspartic) and is supplemented with dl-methionine, dl-tryptophane, and glycine. It contains the "essential" amino acids required by man.
Casein hydrolysate in the amount of $500 \mathrm{cc}$. (50 gm. amino acids) was infused without glucose to eight normal subjects, while fasting, at three rates of administration: approximately $2 \mathrm{mgm}$., $6 \mathrm{mgm}$., and $10 \mathrm{mgm}$. of nitrogen per kilogram per minute, representing infusion times of approximately one hour, 20 minutes, and 10 minutes, respectively. The plasma alpha amino nitrogen was determined prior to the infusion, and at five-minute, one-hour, and four-hour intervals after the infusion was completed. Determinations of the alpha amino nitrogen and of the 10 "essential" amino acids (microbiological assay) were made on urine obtained prior to the infusion, in the first four hours and in the next 20 hours after the infusion was completed.

The infusions were well tolerated. Two subjects who received the $50 \mathrm{gm}$. of amino acids intravenously in approximately 10 minutes noted transient nausea near the end of the infusion.

The ingestion of an estimated $105 \mathrm{gm}$. of protein in the diets of the eight normal subjects during the day prior to infusion only increased the excretion of amino nitrogen above the fasting level by 55 mgm. daily, or approximately 0.4 per cent of the ingested amino nitrogen. The average excretion of the 10 "essential" amino acids on these ad libitum diets was: arginine 9.5 ; histidine 163 ; isoleucine 13.8 ; leucine 7.2 ; lysine 46.8 ; methionine 4.4 ; phenylalanine 14.0 ; threonine 20.9 ; tryptophane 12.7 ; and valine $7.4 \mathrm{mgm}$. per 24 hours.

The blood alpha amino nitrogen values for the eight subjects averaged $3.6 \mathrm{mgm}$. per $100 \mathrm{cc}$. of plasma initially, rose to $22.5 \mathrm{mgm}$. per cent five minutes after the infusion, rapidly fell to $7.2 \mathrm{mgm}$. per cent one hour later, and returned to within normal limits by four hours although most values were slightly above the pre-injection level and averaged $3.9 \mathrm{mgm}$. per cent.

There was an average loss from excretion into the urine of 1 to 16 per cent of the individual amino acids infused, 4.3 per cent of the total 10 "essential" amino acids injected, and 9.5 per cent of the amino nitrogen administered. The increased excretion of both amino nitrogen and individual amino acids was completed within four hours after the infusion by which time the elevated blood amino nitrogen had returned to within normal limits. 
The excretion of amino nitrogen in the urine increased little with more rapid rates of infusion but correlated more closely with the size of the infusion. The "essential" amino acids in the infusion mixture were preferentially retained by the subjects while the dispensable amino acids were more freely excreted in the urine. The greatest retention of the "essential" amino acids was observed at the slowest rate of infusion.

The individual amino acids were not excreted in the urine in the same proportion as administered, so that fairly large percentages of administered threonine and histidine were excreted, intermediate percentages of lysine and tryptophane, and smaller percentages of the other amino acids. With each increase in the rate of the infusion, however, the additional excretion of all the "essential" amino acids more closely resembled the composition of the amino acids infused.

The administration of protein or amino acids orally or intravenously, slowly or rapidly, and in large or small quantity is followed by excretion in the urine of but a small portion of the amino acids given so that the body retains for metabolic purposes most of that administered.

\section{ACKNOWLEDGMENTS}

The authors wish to thank Miss Elaine Hirshberg, Miss Virginia Garrison, and Miss Alice Ballou for their technical assistance.

\section{BIBLIOGRAPHY}

1. Cox, W. M., Jr., and Mueller, A. J., The relative efficiency of different forms of intravenously administered nitrogen on nitrogen balance and amino acid excretion. J. Nutrition, 1946, 31, 581.

2. Silber, R. H., Seeler, A. O., and Howe, E. E., Urinary excretion of alpha amino nitrogen following intravenous administration of amino acid mixtures. J. Biol. Chem., 1946, 164, 639.

3. Barborka, C. J., Carroll, W. W., and Hepler, O. E., Utilization of parenteral protein hydrolysate in the normal. Gastroenterology, 1947, 9, 579.

4. Christensen, H. N., Lynch, E. L., and Powers, J. H., The conjugated, non-protein, amino acids of plasma. III. Peptidemia and hyperpeptiduria as a result of the intravenous administration of partially hydrolyzed casein (Amigen). J. Biol. Chem., 1946, 166, 649.

5. Christensen, H. N., Lynch, E. L., Decker, D. G., and Powers, J. H., The conjugated, non-protein, amino acids of plasma. IV. A difference in the utilization of the peptides of hydrolysates of fibrin and casein. J. Clin. Invest., 1947, 26, 849.

6. Eckhardt, R. D., and Davidson, C. S., The oral and parenteral phenylalanine requirements for nitrogen equilibrium in man. J. Clin. Invest., 1948, 27, 165.

7. Rose, W. C., Progress in conquest of malnutrition by amino acids. Sixth Annual Scientific Award Ceremony of the American Pharmaceutical Manufacturers' Assoc., New York, 1944, p. 18.

8. Stokes, J. L., Gunness, M., Dwyer, I. M., and Caswell, M. C., Microbiological methods for the determination of amino acids. II. A uniform assay for the ten essential amino acids. J. Biol. Chem., $1945,160,35$.

9. Hodson, A. Z., and Krueger, G. M., Essential amino acid content of casein and fresh and processed cow's milk as determined microbiologically on hydrolysates. Arch. Biochem., 1946, 10, 55.

10. Pearce, E. L., Sauberlich, H. E., and Baumann, C. A., Amino acids excreted by mice fed incomplete proteins. J. Biol. Chem., 1947, 168, 271.

11. Hamilton, P. B., and Van Slyke, D. D., The gasometric determination of free amino acids in blood filtrates by the ninhydrin-carbon dioxide method. J. Biol. Chem., 1943, 150, 231.

12. Van Slyke, D. D., MacFadyen, D. A., and Hamilton, P. B., The gasometric determination of amino acids in urine by the ninhydrin-carbon dioxide method. J. Biol. Chem., 1943, 150, 251.

13. Albanese, A: A., The utilization of alpha amino acids by man. I. Tryptophane, methionine and phenylalanine. Bull. Johns Hopkins Hosp., 1944, 75, 175.

14. Levenson, S. M., Adams, M. A., Green, R. W., Lund, C. C., and Taylor, F. H. L., Plasma alpha amino nitrogen levels in patients with thermal burns. New England J. Med., 1946, 235, 467.

15. Eckhardt, R. D., and Davidson, C. S., The rapid injection of a solution of amino acids: A note on its clinical tolerance in man. New England J. Med., 1948, 239, 164.

16. Larson, P. S., and Chaikoff, I. L., The influence of carbohydrate on nitrogen metabolism in the normal nutritional state. J. Nutrition, 1937, 13, 287.

17. Pitts, R. F., A renal reabsorption mechanism in the dog common to glycine and creatine. Am. J. Physiol., 1943, 140, 156.

18. Goettsch, E., Lyttle, J. D., Grim, W. M., and Dunbar, $P$., The renal amino acid clearance in the normal dog. Am. J. Physiol., 1944, 140, 688.

19. Steele, B. F., Sauberlich, H. E., Reynolds, M. S., and Baumann, C. A., Amino acids in the urine of human subjects fed eggs or soy beans. J. Nutrition, 1947, 33, 209.

20. Dunn, M. S., Camien, M. N., Shankman, S., and Block, H., Urinary excretion of twelve amino acids by normal male and female subjects measured microbiologically. Arch. Biochem., 1947, 13, 207.

21. Woodson, H. W., Hier, S. W., Solomon, J. D., and Bergeim, O., Urinary excretion of amino acids by human subjects on normal diets. J. Biol. Chem., 1948, 172, 613.

22. Howe, E. E., Unna, K., Richards, G., and Seeler, A. O., Comparative tolerance to mixtures of natural and racemic amino acids on intravenous infusion in the dog. J. Biol. Chem., 1946, 162, 395. 